\title{
Lateral
}

Journal of the Cultural Studies Association

\section{Review of The Black Shoals: Offshore Formations of Black and Native Studies by Tiffany Lethabo King (Duke University Press)}

by Laura Goldblatt $\mid$ Book Reviews, Issue 9.2 (Fall 2020)

\begin{abstract}
In this ambitious first book, Tiffany Lethabo King disrupts what she sees as settler-colonial studies' tendency to privilege the settler/conquistador as the ethical subject of Western theory. To do so, she undertakes the urgent work of considering historical, ceremonial, imaginative, and theoretical ways that Native and Black studies intersect and overlap within the North American context. Drawing in particular upon Afro-pessimism (for instance Frank Wilderson, Saidiya Hartman, Katherine McKittrick, Alexander G. Weheliye, and Sylvia Wynter) as well as Native studies' refusal of sovereignty as a political, ethical, and material formation (Audra Simpson, Glen Coulthard, Jodi Byrd, and Andrea Smith), King joins the likes of Tiya Miles in seeing as insufficient any account of settler colonialism or Western humanism that does not consider how Black and Native epistemologies and histories intersect.
\end{abstract}

KEYWORDS Afropessimism, Black studies, Native studies, settler colonialism

The Black Shoals: Offshore Formations of Black and Native Studies. By Tiffany Lethabo King. Durham, NC: Duke University Press, 2019, 304 pp. (paperback) ISBN: 978-14780-0636-7. US List: \$27.95.

In this ambitious first book, Tiffany Lethabo King disrupts what she sees as settler-colonial studies' tendency to privilege the settler/conquistador as the ethical subject of Western theory. To do so, she undertakes the urgent work of considering historical, ceremonial, imaginative, and theoretical ways that Native and Black studies intersect and overlap within the North American context. Drawing in particular upon the Afro-pessimist tradition (for instance Frank Wilderson, Saidiya Hartman, Katherine McKittrick, Alexander G.

Weheliye, and Sylvia Wynter) as well as Native studies' refusal of sovereignty as a political, ethical, and material formation (Audra Simpson, Glen Coulthard, Jodi Byrd, and Andrea Smith), King joins the likes of Tiya Miles in seeing as insufficient any account of settler colonialism or Western humanism that does not consider how Black and Native epistemologies and histories intersect.

In a vast and multifaceted archive that ranges from the eighteenth century to 2015 and considers media including maps, film, novels, and sculpture, King demonstrates with each chapter how bridging the gap between Native and Black studies restores friction to the contemporary and historical landscape and unsettles conventional understandings of coalitional politics. Throughout the book, she uses the metaphor of the "shoal"-a 
collection of sand or other debris that causes the tide to become shallow and thereby offset, delay, or otherwise disrupt the water's path-as a critical hermeneutic for her theoretical interventions. King argues that reading Black and Native studies, along with their attendant commitments, together "shoals" or slows the onward march of conquest and settler colonialism, shifting how the rise of Western humanism is narrated, for instance, or demonstrating how Black and Native studies share theoretical and historical commitments. Additionally, she notes that the shoal-as a formation that is neither quite land, nor water-serves as an example of how Native and Black studies can be brought together, challenging interpretations that cast Blackness and Indigeneity in the Americas as oppositions: the former as rootless and the latter as rooted.

Despite these commitments, King neither shies away from the violences of conquest and slavery, nor the ways that Black and Native groups have been pitted against each other. For instance, in her third chapter-which takes up the film Daughters of the Dust (1991) King acknowledges that enslaved labor was often used to clear land and displace Native persons, just as some Native American tribes owned enslaved persons of African descent, and that the two groups remain wary of each other in certain circumstances. True to her guiding metaphor, King leverages these episodes as a kind of shoal, bending her analysis to consider how erotic alliances and desires can create novel, fugitive alliances and allow for unconventional or liberatory worldviews.

In a similar vein, by divulging details about her own identity as a Black woman born in the US, King makes visible the limitations stemming from her own positionality. For instance, in her fourth chapter, she discusses how Black and Native American erotics disfigure Victorian notions of romance. King also notes that her ability to see a Black protagonist's desire for her Native American lover as exciting and respectful stems in part from her vantage point as a Black woman. Rather than excusing or censoring her reaction, King uses the moment as an opportunity to trace how legacies of settler colonialism, slavery, and conquest have permeated the personal, lived experience of the characters in Daughters of the Dust, such that what appears to be lovemaking from one cultural perspective can feel like marginalization from another.

King organizes each chapter around a central event or cultural artifact. Following an introduction where she lays out her theoretical project and the limitations she finds with some of the fields that dominate the humanities and social sciences-namely queer and Marxian theory and white-dominated settler-colonial studies-the first chapter explores the vandalization of the Christopher Columbus statue on the Boston waterfront in 2015. The group or individual involved splashed the statue with red paint and inscribed "BLACK LIVES MATTER!" on the back of the pedestal, a move, which King explains, makes it seem as though the statue is covered with blood. King turns to the subsequent public response to the act (especially those subjects who expressed confusion over why Columbus was being connected with slavery) and to the statue itself to imbed white humanism within the context of conquest and slavery and to demonstrate the category's inability to contain Black and Native American subjectivity. The themes in this first chapter return in her fifth and final chapter where she connects "Revisiting Sycorax," a sculpture by a Black Canadian artist and educator, to emergent ceremonies that create space for Black and Native American solidarities and coalitions.

Her second and third chapters discuss William Gerard de Brahm's eighteenth-century map of the coast of what is now South Carolina and Georgia, in particular the cartouche featuring enslaved laborers in the lower right-hand corner. Here, King argues that while the 
cartouche was intended to cast white European Cartesian logic as rational and dominant, it instead documents the instability slave rebellions and Cherokee-controlled land posed to Cartesian order itself. In her following chapter, she makes fruitful use of an archival accident: based on how the map was folded and preserved, the cartouche has been doubled, its imprint hovering upside-down-a ghostly remnant of itself on the opposite side of the page. Citing this accident as a result of the porousness of the material, King transitions to the film Daughters of the Dust and the ways that indigo dye seeps through the pores of the family featured in the film, staining their hands and showing how their work exceeds the category of labor. The film returns in her penultimate chapter alongside a companion novel written following the film, and the novel Cherokee Rose in an analysis of Black and Native erotics.

King's book is an important participant in a small but growing scholarly movement seeking to understand and unravel the logics of settler colonialism and conquest by breaking down scholarly silos between groups that frequently interacted and interact. Moreover, what King has so well begun can be built on by other scholars. For example, King finds Marx's category of labor insufficient for her purposes. Her critique could provide an opening for scholars currently working in a Marxist tradition to reconsider the relationship of labor to settler colonialism and slavery. Were they to make the attempt, they would find The Black Shoals to be a useful resource. There are some missed opportunities, however. At times, King's various metaphors-the shoal, the pore, cartography, and so on-seem unrelated to each other or compete for attention. Further, the book sometimes treats certain fields as monolithic. For instance, in her critique of Marx's category of labor she refrains from quoting Marx or more recent Marxist scholars' work on labor, settler colonialism, or enslavement, making it unclear which aspects of the Marxian sense of labor she finds insufficient. The methods King has developed in The Black Shoals could be productively trained on this literature to advance the arguments so well begun here.

\section{Author Information}

\section{Laura Goldblatt}

Laura Goldblatt is an assistant professor at the University of Virginia with a PhD in English Literature from same. Her peer-reviewed work has appeared in or is forthcoming in Mississippi Quarterly, the .Journal of American Studies, Social Text, Winterthur Portfolio, Pedagogy, and Works and Days, and an edited volume about the August 12th, 2017 violence in Charlottesville. She is currently at work on two monographs. The first explores the reception of statesponsored reproductions of literary and popular texts about U.S. national expansion used for propagandistic purposes. Yet rather than focus on the formal features of the artifacts themselves, she examines their use value for groups dispossessed by the logic of late capitalism, such as Native and Black Americans, during the long twentieth century. Additionally, along with Professor of Anthropology Richard Handler, she is at writing on a monograph about twentieth-century U.S. postage stamps that takes moral circulation as its theme.

View all of Laura Goldblatt's articles. 


\section{Article details}

Laura Goldblatt, "Review of 'The Black Shoals: Offshore Formations of Black and Native Studies' by Tiffany Lethabo King (Duke University Press)," Lateral 9.2 (2020).

https://doi.org/10.25158/L9.2.8

This content is licensed under a Creative Commons Attribution-NonCommercial 4.0 International License. Copyright is retained by authors.

Lateral is the peer-reviewed, open access journal of the Cultural Studies Association.

ISSN 2469-4053 